ISSN 2656-839X

\title{
KONSEP PENDIDIKAN ISLAM HOLISTIK DALAM MEMENANGKAN PERSAINGAN DI ERA MILENEAL
}

\author{
Amie Primarni (amieprimarni.dr@laaroiba.ac.id) \\ Program Studi Pendidikan Agama Islam \\ Pascasarjana IAIN Laa Roiba Bogor
}

\begin{abstract}
This study aims to produce an Educational Concept that is able to win competition in the Mileneal Era. This study uses a qualitative method with a literature study approach. This research approach uses analysis from the perspective of anthropology, sociology and educational psychology. Using triangulation techniques, the writer tries to construct the construct of a learning concept. In conclusion, the results of this study resulted in a concept of The Foundation Of Learning Process, a foundation of continuous learning that gradually develops spiritual, intellectual, physical and emotional development abilities, in a planned, structured manner.
\end{abstract}

Keywords: Islamic Education, Holistic Education.

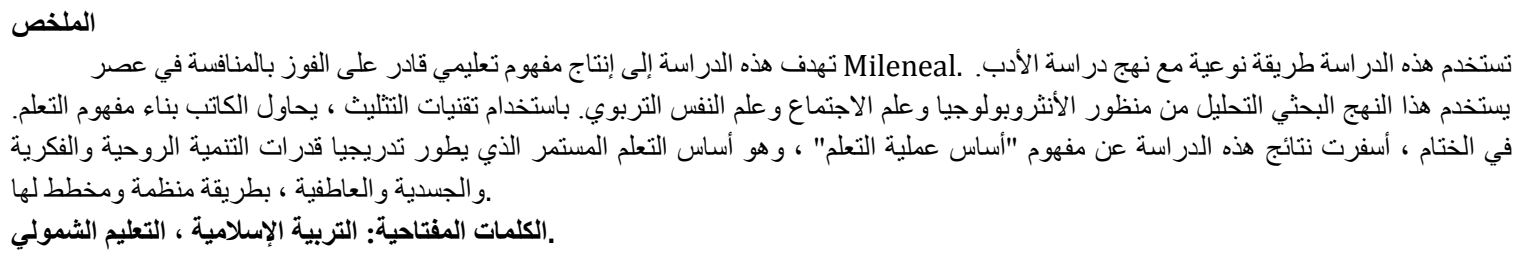

\section{ABSTRAK}

Penelitian ini bertujuan untuk menghasilkan sebuah Konsep Pendidikan yang mampu memenangkan persaingan di Era Mileneal. Penelitian ini menggunakan metoda kualitatif dengan pendekatan study literatur. Pendekatan penelitian ini menggunakan analisa dari sudut pandang antropologi, sosiologi dan psikologi pendidikan. Menggunakan tehnik triangulasi, kemudian penulis mencoba membangun kontruk sebuah konsep pembelajaran. Kesimpulan, hasil penelitian ini menghasilkan sebuah konsep The Foundation Of Learning Process, sebuah fondasi pembelajaran yang berkesinambungan yang mengembangkan secara bertahap kemampuan pengembangan spiritual, intelektual, fisik dan emosi, secara terencana, terstruktur.

Kata Kunci : Pendidikan Islam, Pendidikan Holistik.

\section{A. PENDAHULUAN}

Manajemen jalur pendidikan berjalan sendiri-sendiri, tidak ada hubungan secara sistemik antara jalur pendidikan formal, pendidikan non formal, dan pendidikan informal. Sehingga output dan outcome belum memenuhi kebutuhan masyarakat dan bangsa dalam bersaing dengan tatanan kehidupan global dana bidang ekonomi, Ilmu pengetahuan dan teknologi, serta beradaban dunia. Demikian pendahuluan ini yang merupakan permasalahan yang dihadapi saat ini dan sekaligus akan dibahas dalam makalah ini.

Munculnya konsep jalur pendidikan formal, nonformal dan informal dimulai pada tahun 1967 saat konferensi international diselenggarakan di Williamsburg USA, pengakuan para perencana dan pakar pendidikan tentang munculnya krisis pendidikan dunia ( world educational crisis) sebagaimana dikemukakan oleh Coombs (1968) telah menjadi meluar. Terdapat kepedulian terhadap 
ketidaksesuaian kurulullum. Dalam konteks ini pertumbuhan pendidikan dan pertumbuhan ekonomi tidak sejalan dan pekerjaan tidak muncul secara langsung sebagai hasil pendidikan. Banyak negara mengalami kesulitan untuk membiayai perluasan pendidikan formal. Disimpulkan dalam konferensi tersebut bahwa sistem pendidikan formal beradaptasi sangat lambat terhadap perubahan sosial ekonomi yang disebabkan bukan semata-mata karena konservatisme pendidikan sekolah, tetapi juga oleh kelambanan (inertia) masyarakat itu sendiri. Dari titik awal pemberangkatan inilah para perencana pendidikan dan ekonom di Bank Dunia mulai membedakan antara pendidikan formal, nonformal, dan informal ( Fordham 1993:2) Pada waktu yang hampir bersamaan ada gerakan dalam UNESCO mengenai pendidikan sepanjang hayat ( life-long education) dan masyarakat gemar belajar ( the learning society) yang kulminasinya tertuang dalam buku Learning To Be. Pendidikan Sepanjang Hayat menjadi the master concept dalam membangun sistem pendidikan ( UNESCO 1972:182)

Pengakuan terhadap pendidikan formal, informal dan nonformal mengacu pada definisi yang dikemukakan Coombs (1968). Pendidikan sekolah (formal education) didefinisikan oleh Coombs sebagai sistem pendidikan yang berstruktur, bertingkat, berjenjang dimulai dari sekolah dasar sampai universitas dan yang setaraf, termasuk kegiatan belajar yang berorientasi akademik dan umum, bermacam-macam spesialis, dan latihan teknik serta latihan profesional.

Pendidikan informal (informal education) menurut Coombs adalah proses yanrlangsung seumur hidup, yang dalam proses itu setiap orang memperoleh nilai, sikap, ketrampilan, dan pengetahuan yang berasal dari pengalaman hidup sehari-hari, seperti dari keluarga, teman sepermainan, tetangga, pekerjaan, perpustakaan,pasar media massa, dll.

Pendidikan nonformal (nonformal education) menurut Coombs adalah setiap kegiatan pendidikan yang diorganisasikan di luar sistem persekolahan yang mapan, baik dilakukan secara terpisah atau sebagai bagian penting dari kegiatan yang lebih besar, dan dilakukan secara sengaja untuk melayani peserta didik tertentu guna mencapai tujuan belajarnya. Menarik untuk mengembalikan sejenak pada proses pembagian jalur pendidikan, sebab pendidikan khususnya di Indonesia berkembang dan mendapat perhatian baru pada era sesudah Kemerdekaan (1945) Pada masa penjajahan baik Belanda maupun Jepang, pendidikan di Indonesia dikuasasi oleh Pemerintah Jajahahan sebagai media untuk mewujudkan tujuan mereka. Maka muncullah pendidikan yang berstrata, misalnya pendidikan untuk kamu penjajah, kaum bangSAWan, dan rakyat kebanyakan.

Oleh sebab itu ketika pada masa pasca kemerdekaan maka pengambilan design untuk pendidikan di Indonesia banyak mengambil dari design pendidikan Barat. Sehingga ada Pertanyaan untuk hal itu, sudah tepatkah design pendidikan yang kita ambil ? tepatkah Indonesia menggunakan ketiga jenis pembagian jalur pendidikan seperti diatas ? Indonesia memiliki Falsafah negara sendiri, yang telah mengakomodir nafas atau ruh, atau jati diri Indonesia yang berlandaskan keTuhanan Yang Maha Esa, yang menjadi core bagi seluruh aktifitas di Indonesia, termasuk aktifitas pendidikan. Sementara itu para ilmuwan Pendidikan Barat sekalipun telah mengakui bahwa Ilmu - apalagi yang objek kajiannya manusia - tidaklah bebas nilai. Jika demikian maka pendidikan di Indonesia haruslah di jiwai, dan dilandasi oleh nilai KeTuhanan Yang Maha Esa.

Jika kita lihat pembagian jalur pendidikan di atas, adalah sebuah pemecahan masalah pendidikan di Barat yang pada waktu itu, terjadi kesenjangan dimana output pendidikan tidak mampu memecahkan problem ekonomi. Pendidikan bukan solusi dalam bekerja. Kondisi ini dialami oleh hampir seluruh negara pada masa itu. Mengapa ini menjadi penting dibahas lebih dulu sebab pembagian jalur pendidikan ini kemudian dijadikan konsep secara global dalam bidang pendidikan. Padahal dalam tujuan pendidikan dasar di Amerika sebagai negara sekuler maka fungsi dan tujuan negaranya tidak mengedepankan unsur keImanan, KeTaqwaan dan akhlak mulia. Fungsi dan tujuan pendidikan dasar di Amerika adalah (1) creation of sociability and national spirit (2) counciusness of health (3) development of self-reliance (4) development of socialization (5) development of creativity. Sementara Indonesia adalah Negara yang mendasarkan fondasi negaranya pada azas Ketuhanan Yang 
Maha Esa. Karena itu perlu dikaji pula, apakah pembagian jalur di atas mampu mengakomodir itu. Makalah ini mencoba mencari bentuk yang paling tepat dalam pendidikan di Indonesia.Termasuk masalah penggunaan paradigma, teori ( grand theory - ground theory) dan konsep, hingga implementasinya.

\section{B. TINJUAN PUSTAKA \& RISET TERDAHULU}

Pendidikan Formal, adalah istilah yang digunakan untuk mengacu pada pengertian penyelenggaraan sekolah yang resmi diberlakukan dan diakui pada sebuah negara, dengan mengacu pada landasan filosofi negara yang dianut, dengan sistem kurikullum yang mengacu pada visi dan misi negara. Di Indonesia berdasarkan jalur pendidikan ( Syaodih, 2007) dibedakan atas pendidikan formal, informal dan nonformal. Jenjang pendidikan formal meliputi pendidikan dasar, menengah, dan pendidikan tinggi.

Tujuan pendidikan dasar, berfungsi menanamkan nilai, sikap, rasa keindahan, serta memberikan dasar-dasar pengetahuan, kemampuan, dan kecakapan membaca, menulis, dan berhitung serta kapasitas belajar peserta didik untuk melanjutkan ke pendidikan menengah dan atau hidup di masyarakat, sejalan dengan pencapaian tujuan pendidikan nasional ( Bab IV, bagian 1, Pasal 12, Ayat 1). Di Indonesia yang disebut dengan pendidikan dasar meliputi Sekolah Dasar dan Sekolah Menengah Pertama.

Tujuan pendidikan menengah ( Ibrahim,2007) pendidikan menengah menjembatani pendidikan dasar dan pendidikan tinggi. Secara umum, pendidikan menengah dan sekolah menengah saling berkaitan; pendidikan menengah lebih menunjukkan jenjang pendidikan, sedangkan sekolah menengah lebih menunjukkan institusi penyelenggara. Yang dimaksud Sekolah Menengah meliputi Sekolah Menengah Umum dan Kejuruan. Perbedaan kelompok pada Sekolah Menengah ini dimaksudkan untuk mengelompokkan berdasarkan tujuan, Sekolah Menengah Umum ditujukan bagi mereka yang akan melanjutkan ke jenjang berikutnya, sementara Sekolah Kejuruan dipersiapkan untuk memasuki lapangan kerja.

Tujuan pendidikan tinggi, pendidikan tinggi merupakan pendidikan formal yang menyelenggarakan program pendidikan diploma, sarjana, magister, spesialis, dan doktor. Pendidikan tinggi diselenggarakan dengan sistem terbuka. ( UUSPN 20/2003 Pasal 20). Tujuan pendidikan tinggi (1) menyiapkan peserta didik menjadi anggota masyarakat yang memiliki kemampuan akademik dan/ atau profesional yang dapat menerapkan, mengembangkan, dan atau memperkaya khasanah ilmu pengetahuan, teknologi dan/atau kesenian, dan (2) mengembangkan dan menyebarluaskan ilmu pengetahuan, teknologi dan/atau kesenian serta mengupayakan penggunaannya untuk meningkatkan taraf kehidupan masyarakat dan memperkaya budaya nasional. (PP No.66.1999, Pasal 2)

\section{Pendidikan Nonformal}

Pendidikan nonformal dan informal termasuk dalam pendidikan luar sekolah. Fungsi pendidikan luar sekolah terhadap pendidikan sekolah meliputi fungsi subtitusi, komplemen, dan suplemen, selain sebagai jembatan pendidikan sekolah menuju dunia kerja dan sebagai wahana untuk mempertahankan dan mengembangkan kehidupan. Pendidikan luar sekolah ditinjau dari komponen tujuan, waktu, pelaksanaan, materi pembelajaran, penyampaian, dan pengawasan . Pendidikan luar sekolah bertujuan melayani warga belajar agar berkembang sedini mungkin dan sepanjang hayat, memiliki pengetahuan, ketrampilan, dan sikap mental yang diperlukan untuk mengembangkan diri, serta memenuhi kebutuhan belajar yang tidak disediakan oleh pendidikan sekolah. Di Indonesia jenis program pendidikan luar sekolah seperti pendidikan kecakapan hidup, anak usia dini, kepemudaan, 
keaksaraan, kesetaraan, pemberdayaan perempuan, serta ketrampilan dan pelatihan kerja.( Sudjana, 2007)

Pendidikan informal adalah pendidikan yang dilakukan oleh keluarga dan lingkungan untuk menanamkan nilai-nilai agama, moral, etika, kepribadian, estetika, dan ketrampilan fungsional dalam bentuk kegiatan belajar secara mandiri (El Chumaedy, 2002)

\section{Posisi Pendidikan Islam}

Pendidikan di tengah medan kebudayaan (culture area), berproses merajut dua substansi aras kultural, yaitu di samping terartikulasi pada upaya pemanusiaan dirinya, juga secara berkesinambungan mewujud ke dalam pemanusiaan dunia di sekitarnya (man humanizes himself in humanizing the world around him) (J.W.M. Bakker, SJ; 2000: 22). Kenyataan ini nampaknya amat begitu diinsafi oleh para designer awal dan founding fathers bangsa ini, hingga kemudian cita-cita yang mengkristal dalam tujuan pendidikan nasional (Mukaddimah UUD '45) kita, betul-betul terarah ke pengertian seperti itu. Dalam prakteknya, pengejawantahan cita-cita pendidikan nasional, nampaknya tidak harus melulu ditempuh melalui jalur formal secara berjenjang (hierarchies), yang dilaksanakan mulai dari Pendidikan Pra-Sekolah (PP. No. 27 Tahun 1990), Pendidikan Sekolah Dasar (PP. No. 28 Tahun 1990), Pendidikan Sekolah Menengah (PP. No. 29 Tahun 1990) dan Pendidikan Perguruan Tinggi (PP. No. 30 Tahun 1990), akan tetapi juga mengabsahkan pelaksanaan pendidikan secara nonformal dan in-formal (pendidikan luar sekolah) (UU Sisdiknas, 2003).(El Chumaedy,2008)

Artikulasi pendidikan terakhir ini, basisnya diperkuat mulai dari pendidikan di lingkungan keluarga, masyarakat dan lembaga-lembaga pendidikan swasta. Paralel dengan pelaksanaan pendidikan luar sekolah dalam pelbagai bentuk dan ragamnya, terdapat satu institusi pendidikan yang telah mengakar lama dalam sejarah pendidikan di Indonesia, yaitu terutama pendidikan Islam yang diselenggarakan di pesantren-pesantren (Islamic boarding school). Sebagai institusi pendidikan Islam tradisional, pesantren sudah sejak lama survive dalam sejarah perkembangan pendidikan Indonesia. Ia telah terbukti banyak memberi sumbangan bagi upaya mewujudkan idealisme pendidikan nasional, yang bukan sekedar hanya meningkatkan kualitas sumber daya manusia (human resource) pada aspek penguasaan sains dan tekhnologi an sich, melainkan juga lebih concern dalam mencetak warga negara Indonesia yang memiliki ketakwaan terhadap Tuhan Yang Maha Esa, terutama dalam memupuk generasi yang bermoral baik (akhlaq al-karimah).

Indegenousitas pesantren kontras berbeda dengan praktek pendidikan pada intitusi pendidikan lainnya, sehingga dinamika sekaligus problematika yang muncul kemudian, juga menampilkan watak yang khas dan eksotik. Di era globalisasi sekarang ini, Alfin Toffler membayangkan akan terciptanya 'masyarakat informasi' (the informasional society) yang sulit untuk dihindari oleh negara manapun di permukaan bumi ini, termasuk Indonesia. Sehingga, fenomena globalisasi yang begitu cepat mengalami akselerasi dalam pelbagai aspek, sebagai konsekuensi logis dari penerapan high-tech (tekhnologi tinggi), menyebabkan bangsa Indonesia tergiring pada pola interaksi yang amat cepat dan massif dengan negara-negara lain di dunia. Dalam fase masyarakat informasi inilah, pesantren semakin menghadapi tantangan yang tidak ringan dan lebih kompleks ketimbang periode waktu sebelumnya.

Di tengah pergulatan masyarakat informasional, pesantren 'dipaksa' memasuki ruang kontestasi dengan institusi pendidikan lainnya, terlebih dengan sangat maraknya pendidikan berlabel luar negeri yang menambah semakin ketatnya persaingan mutu out-put (keluaran) pendidikan. Kompetisi yang kian ketat itu, memposisikan institusi pesantren untuk mempertaruhkan kualitas out-put pendidikannya agar tetap unggul dan menjadi pilihan masyarakat, terutama umat Islam. Ini mengindikasikan, bahwa pesantren perlu banyak melakukan pembenahan internal dan inovasi baru agar tetap mampu meningkatkan mutu pendidikannya. (Al-Attas, 2008) 


\section{Pemaknaan Pendidikan Islam}

Dalam kajian ini penulis membatasi pengertian pendidikan dalam konteks pendidikan Islam dengan mengutip definisi pendidikan Islam yang diutarakan oleh Syed. M. Naquib M Al-Attas (Al-Attas, 2008) yang menurut hemat penulis memiliki point yang cukup signifikan untuk dijadikan Grand Teory Pendidikan Islam yang lebih mampu menjabarkan dan digunakan secara tepat ketika mengkaji khazanah ilmu pengetahuan Islam khususnya yang memiliki objek kajian manusia. Dimana dimensi yang paling membedakannya dengan paradigma pemikiran Barat termasuk dalam hal pendidikan adalah penggunaan paradigma adanya Tuhan sebagai pengatur dan penentu.

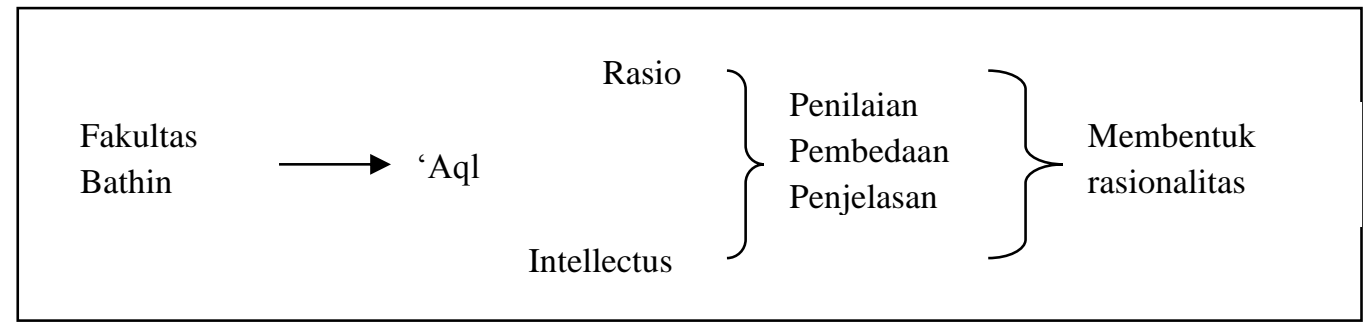

Makna, menuruAl-Attas ( Al Attas, 2008) dilihat dengan cara sebagaimana telah dirumuskannya diatas, adalah suatu citra mental yang di dalamnya sebuah kata atau ungkapan diterapkan untuk menunjukkannya, Ketika kata atau ungkapan tersebut menjadi suatu gagasan atau pengertian di dalam pikiran ('aql, dengan mengacu pada nuthq), maka ia disebut sebagai "yang terpahamkan" ( mafhum). Sebagai bentuk yang dapat dicernakan yang terbentuk sebagai jawaban pada pertanyaan "apakah ini ?" ia disebut sebagai esensi ( mahiyah). Jika dianggap sebagai sesuatu yang ada di luar pikiran, yakni secara objektif, ia disebut sebagai " realitas" (haqiqah). Dilihat sebagai suatu hakikat khas yang terbedakan dari yang lain, ia disebut sebagai 'individualita' atau 'periada individual'. Dengan cara dan dalam konteks bahasan ini, kita katakan bahwa yang membentuk makna - atau definisi makna adalah pengenalan tempat-tempat segala sesuatu di dalam suatu sistem, yang terjadi ketika relasi yang dipunyai sesuatu dengan yang berada di dalam sistem tampak jelas dan terpahamkan.(Al-Attas, 2008)

Menurut Al-Attas ( Al-Attas, 2008) unsur penting kedua yang melekat di dalam pendidikan adalah kandungannya, yang disini disebut sebagai "sesuatu". Sesuatu itu adalah Ilmu, pertanyaannya apakah yang disebut ilmu ? atau Terdiri dari apa sajakah Ilmu itu? Ada banyak definisi yang menguraikan sifat Ilmu, tetapi yang relevan di sini adalah definisi epistemologis. Orang-orang muslim sepakat bahwa semua ilmu datang dari Allah. Dan kita juga tahu bahwa cara kedatangannya, dan fakultas serta indera yang menerima dan menafsirkan tidaklah sama. Oleh karena semua pengetahuan datang dari Allah dan ditafsirkan oleh jiwa lewat fakultas-fakultas spiritual dan fisikalnya, maka definisi yang paling cocok - dengan mengacu kepada Allah sebagai asalnya - adalah bahwa ilmu pengetahuan ialah kedatangan ( hushul) makna sesuatu atau suatu objek pengetahuan di dalam jiwa. Sedangkan, dengan mengacu kepada jiwa sebagai penafsirnya, pengetahuan adalah sampainya (wushul) jiwa pada makna sesuatu atau suatu objek pengetahuan.

Konsep lain yang dimaknai baru oleh Al-Attas adalah adab, adab (Al-Attas, 2008) melibatkan tindakan untuk mendisplinkan pikiran dan jiwa ; hal ini berarti pencapaian kualitas-kualitas dan sifatsifat yang baik oleh pikiran; penyelenggaraan tindakan-tindakan yang betul, bukan yang menyeleweng, yang benar atau tepat dan bukan yang salah; penyelamatan diri dari kehilangan kehormatan. Jadi adab, sebagai tindakan disipliner, pencapaian selektif, tingkahlaku yang benar dan pemeliharaan kualitatif berikut segala pengetahuan yang terkandung di dalamnya, merupakan pemenuhan tujuan pengetahuan. Berkaitan dengan definisi makna diatas dan karena pengetahuan terdiri dari sampainya, baik dalam arti hushul dan wushul, makna di dalam dan oleh jiwa, maka AlAttas mendefinisikan pengetahuan (Al-Attas, 2008) sebagai pengenalan tempat-tempat yang tepat dari segala sesuatu di dalam penciptaan sedemikian rupa, sehingga hal ini membawa kepada pengenalan 
tentang tempat yang tepat dari Tuhan dalam tatanan wujud dan keperiadaan. Agar pengetahuan bisa dijadikan "pengetahuan", kita masukkan unsur dasar pengakuan di dalam pengenalan, dan mendefinisikan kandungan pendidikan (Al-Attas, 2008) sebagai pengenalan dan pengetahuan tempattempat yang tepat dari segala sesuatu di dalam keteraturan penciptaan sedemikian rupa, sehingga hal ini membimbing ke arah pengenalan dan pengakuan tempat-tempat Tuhan yang tepat dalam tatanan wujud dan keperiadaan. Kemudian Al-Attas mendefinisikan pendidikan termasuk pula proses pendidikan (Al-Attas, 2008) sebagai, pengenalan dan pengakuan yang secara berangsur-angsur ditanamkan ke dalam manusia tentang tempat-tempat yang tepat dari segala sesuatu di dalam tatanan penciptaan sedemikian rupa, sehingga hal ini membimbing ke arah pengenalan dan pengakuan tenpat Tuhan yang tepat di dalam tatanan wujud dan keperiadaan. Menurut Al-Attas, dalam pengertian dan penjelasan tersebut di atas, maka kata-kata Nabi Suci : Tuhanku telah mendidikku dan dengan demikian menjadikan pendidikanku yang paling baik" bisa diuraikan dengan kata-kata sendiri sebagai berikut : "Tuhanku telah membuatku mengenali dan mengakui, dengan apa (yaitu adab) yang secara berangsur-angsur telah Dia tanamkan ke dalam diriku, tempat-tempat yang tepat dari segala sesuatu di dalam penciptaan, sehingga hal itu membimbingku ke arah pengenalan dan pengakuan tempat-Nya yang tepat di dalam tatanan wujud dan keperiadaan dan sebagai akibatnya, Ia telah membuat pendidikanku yang paling baik". sehingga tidak perlu lagi ada kebimbangan maupun keraguan dalam menerima proposisi bahwa konsep pendidikan dan proses pendidikan telah tercakup di dalam istilah ta'dib dan bahwa istilah yang tepat untuk menunjukkan "pendidikan" di dalam Islam sudah cukup terungkapkan olehnya. Demikian pemikiran Al-Attas tentang konsep pendidikan.

\section{Teori Sistem}

Menggabungkan dan kemudian mencari konsep, sistem, proses dan model pendidikan dalam memecahkan masalah seperti diatas membutuhkan sebuah pendekatan yang holistik sehingga dalam makalah ini penulis menggunakan pendekatan Teori Sistem (Nasuka,2005) dengan beberapa pertimbangan antara lain : (1) Makin meningkatnya kompleksitas dalam kehidupan manusia (2) Makin meningkatnya interdependensi dunia (3) Terjadinya revolusi dalam teori dan praktek ((manajemen khususnya) (4) Makin meningkatnya kesadaran global, tetapi sekalipun demikian orang tetap menitikberatkan pengambilan keputusan lokal. (5) Belajar dan pembelajaran semakin penting.

Kajian ini sesuai dengan kerangka berfikir sistem yang menurut Nasuka ( Nasuka,2005) adalah cara berfikir yang memandang sesuatu sebagai satu keseluhan dari bagian-bagian yang saling berhubungan/interrelasi dan saling ketergantungan atau interdependensi. Metode berfikir sistem mempertimbangkan semua unsur-unsur dan faktor lingkungan yang berpengaruh terhadap proses pencapaian tujuan serta kemungkinan dampak yang ditimbulkannya. Pemikiran sistem ini memungkinkan penulis menggunakan model-model sebagai ciri pendekatan pemikiran sistem (Nasuka, 2005) untuk memberikan kemudahan dan kesederhanaan dalam memahami konsep, proses, dan sistem itu sendiri yang dalam hal ini adalah konsep, sistem, proses dan model pendidikan holistik.

Penulis menggunakan pendekatan sistem yang memiliki perbedaan penting dibandingkan dengan pendekatan analitikal yang lebih menekankan pada pendekatan parsial, dengan berpedoman pada credo: "keseluruhan adalah jumlah dari bagian-bagian " (The whole is just the sum of its parts)". Pada sisi lain, credo pendekatan sistem justru menyatakan bahwa "keseluruhan melebihi jumlah dari bagian ". (The whole is more then the sum of its parts). Hal ini berkaitan erat dengan terjadinya sinergi dalam sistem. Kajian ini lebih tepat menggunakan Teori Sistem yang mampu menggambarkan hubungan antar elemen dalam interrelasi, interdependensi dan interrelasi pada elemen manusia yang memang tidak pernah bisa dipisahkan secara mutlak atau diambil hanya salah satu elemen atau subelemen untuk meniadakan adanya fungsi kesalinghubungan diantara elemen seperti dalam pendekatan analitikal yang menggunakan paradigma Descartes atau Newtonian yang memisahkan tubuh dan pikiran. Manusia bukanlah mesin, yang dapat dikaji secara terpisah-pisah, sebab pada 
manusia itulah justru terjadi kesatupaduan antara jasad ( raga - fisik - inderawi ) dan ruh ( jiwa ) serta emosi ( nafs). Dan keutuhan tumbuhkembang elemen inilah yang dapat menandakan bahwa manusia tumbuh secara ragawi, mental dan jiwa dalam keseimbangan yang dinamis. Pertumbuhan dan perkembangan manusia dalam kasat mata - makro - misalnya dari pertambahan usia dimana perkembangan tubuh membutuhkan waktu - terlihat lambat, tetapi pertumbuhan dan perkembangan manusia yang tak terlihat baik mikro - sel, molekul- maupun yang tak terlihat disebabkan jiwa dan nafs yang bergerak sangat cepat ini dapat terlihat ketika pada menit tertentu manusia dapat berubah dari emosi kecewa, sedih, marah, kemudian kembali tenang.

Sebagai tolok ukur pendekatan Teori Sistem ini ( General Systems Theory) , maka hasil pemikiran disertasi ini memiliki ciri-ciri : Interdependensi ( saling ketergantungan ), Holism ( satu kesatuan yang utuh) ,Mencari tujuan ( goal seeking ) ,Adanya Input - Proses dan - Output ,Adanya kemungkinan entropi (penurunan atau pengurangan sumber daya karena diperlukan untuk melakukan proses) ,Adanya unsur regulasi ( pengaturan) ,Kegiatan transformasi ( perubahan ) ,Adanya hierarki ( tingkatan) ,Munculnya gejala diferensiasi dan ,Adanya unsur equifinality ( kesamaan pencapaian hasil akhir )

Tidak adanya hubungan yang sistemik ( manajemen ) antara jalur pendidikan formal, nonformal dan informal, mengakibatkan baik dalam proses, hasil maupun dampak dari pendidikan yang ada saat ini dirasa kurang memenuhi kebutuhan dalam tatanan globalisasi. Pendidikan individu, kemasyarakatan, dan kenegaraan sesungguhnya adalah sebuah sistem yang saling berhubungan yang tidak dapat direncanakan secara parsial melainkan harus secara utuh. Oleh sebab itu dalam makalah ini penulis mencoba mengkaji dengan pendekatan psikologi, antropologi dan sosiologi untuk menemukan konsep yang diasumsikan dapat diterapkan dalam di Indonesia.

\section{METODOLOGI PENELITIAN}

Penelitian ini mengunakan metode penelitian kualitatif dengan studi literatur menggunakan pendekatan psikologi, antropologi, dan sosiologi. Sebelum masuk ke dalam pendekatan di atas maka penulis akan memulainya dengan mendiskripsikan Indonesia sebagai sebuah sistem kenegaraan, kemasyarakatan dan individu.

Sebagai sebuah sistem kenegaraan Indonesia memilisi dasar negara yang memiliki filosofi yang membedakannya dengan negara lain. Dasar Negara, atau kerangka acuan negera Indonesia adalah Pancasila. Sehingga segala rencana yang dibuat oleh dan untuk rakyat Indonesia berlandaskan pada dasar negara Pancasila. Mengkaji Dasar Negara Pancasila yang terdiri atas lima sila, (1) Ketuhanan Yang Maha Esa (2) Kemanusiaan yang adil dan beradab (3) Persatuan Indonesia (4) Kerakyatan yang dipimpin oleh hikmah kebijasanaan dalam permusyawaratan dan perwakilan (5) Keadilan sosial bagi seluruh rakyat Indonesia. Menjadi hal yang penting, sebab Pendidikan di Indonesia mengalami stagnan yang cukup lama, sehingga Ilmu Pendidikan sendiri berkembang lebih lambat di Indonesia.

Ilmu selalu diwarnai oleh pandangan hidup manusianya, termasuk pendidikan sebagai ilmu maupun sebagai praksis, selalu diwarnai oleh pandangan hidup. Diantara pandangan hidup yang ada adalah Rasionalisme ( Capra,2007). Rasionalisme ialah paham yang mengatakan bahwa kebenaran diperoleh melalui akal dan diukur dengan akal. Pendidikan harus mampu mendidik manusia menjadi manusia. Tujuan pendidikan ialah meningkatkan derajat kemanusiaan manusia. Sebenarnya manusia yang memiliki derajat kemanusiaan yang tinggi itulah yang dapat disebut manusia. Dengan apa manusia dididik menjadi manusia ? Dapatkah kita membayangkan seandainya pendidikan itu dirancang hanya berdasar karakteristik rasionalisme yang mengatakan bahwa kebenaran itu semuanya relatif. Tahun 1880 Nietzsche mengingatkan bahwa budaya Barat telah berada di pinggir jurang kehancuran, sebabnya ialah karena Barat terlalu mendewakan rasion. Pada tahun 1980an Frijtof Capra ( Capra, 2007) mengatakan bahwa budaya barat telah hancur, penyebabnya adalah 
karena terlalu mendewakan rasio. Mendewakan rasio artinya menjadikan rasio satu-satunya sumber dan pengukur kebenaran.

Hal yang paling mendasar dalam zaman global ini ialah masalah nilai.Nilai, sekarang sedang mengglobal. Setiap negara, setiap kelompok orang, bahkan setiap orang ingin orang lain - dimana saja dan kapan saja - menganut nilai yang diyakininya benar. Sekular ingin nilai-nilai mereka dianut semua orang. Untuk tujuan itu orang menggunakan berbagai alat, dan cara. Demikianlah proses globalisasi itu berlangsung. Globalisasi adalah globalisasi nilai-nilai (Tafsir,2006). Tugas pendidikan, termasuk pendidikan di sekolah, yang paling utama adalah menanamkan nilai-nilai.

\section{Dasar bagi Nilai-nilai Pendidikan di Indonesia}

Nilai adalah harga, sesuatu barang bernilai tinggi karena barang itu "harganya" tinggi. Bernilai artinya berharga. Dalam garis besar hanya ada tiga macam ukuran nilai, yaitu baik-buruk, benar-salah, dan indah-tidakindah. Nilai benar-salah digunakan dalam ilmu (sains) Nilai baik-buruk digunakan dalam etika atau yang semacamnya. Nilai indah-tidak indah digunakan untuk menetapkan seni. Diluar itu semua kita mengenal nilai agama seperti halal-haram, wajib-sunnah, dsbnya. Nilai-nilai dalam agama agaknya masuk sebagian ke nilai benar-salah, baik-buruk, dan indah-tidak indah ( Tafsir, 2006) Dalam hal ini penulis ingin mengatakan bahwa nilai-nilai agama tidaklah parsial, melainkan utuh. Nilainilai mencakup nilai benar-salah, baik-buruk, dan indah-tidakindah. Karena itu dalam istilah kebudayaan sulit menentukan ukuran d baik-buruknya suatu budaya, sebab tolok ukuran yang digunakan berbeda dan sangat subjektif tergantung pada keyakinan dan perasaan. Isi kebudayaan itu hampir tidak pernah hanya bernilai benar-salah saja atau baik buruk saja; isi kebudayaan itu hampir selalu mengandung sekurang-kurangnya dua nilai tersebut. Kita ingin kebudayaan kita benar dan salah, bila mungkin juga indah ( Tafsir, 2006) Jika kita akan mengkaji dan mencari solusi agar terjadi kesatupaduan dalam pendidikan maka kita harus sepakati dulu, mau seperti apa hasil pendidikan kita.

\section{OutPut dan Outcome}

Istilah ini muncul dalam Teori Sistem yang saat ini digunakan dalam kajian Ilmu Sosial karena lebih tepat sebab pengertian Ilmu Sosial itu sendiri berputar di sekitar manusia dengan objek kajiannya yang dikaitkan dalam hubungan sosial. Demikian pula lingkup bahasannya tidak akan terlepas dari kaitan dengan : tingkah laku individu maupun kelompok, pemenuhan kebutuhan, hakikat keberadaannya di dunia, hasil budaya, emosi dan pengalaman hidupnya (Nasuka, 2005).Ada dua bentuk hasil yang diinginkan dalam penelitian yang objek kajiannya manusia, pertama adalah hasil yang dapat terukur secara kuantitatif, kedua adalah hasil yang bentuknya kualitatif. Output adalah keluaran yang mengindikasikan kuantitatif, sementara Outcome adalah keluaran yang lebih mengindikasikan kualitatif.Oleh sebab itu mengkaji masalah manajemen jalur pendidikan di Indonesia dapat diukur secara kuantitatif dengan menghasilkan lulusan yang mampu bersaing di bidang ekonomi, pengetahuan dan teknologi, sementara dalam urusan peradaban bangsa dan dunia ukurannya adalah kualitatif.

\section{Pendekatan Antropologi, Sosiologi dan Psikologi}

Pendekatan Antropologi secara garis besar antropologi menyumbangkan pemikiran ke dalam pendidikan dengan mengatakan bahwa keragaman merupakan unsur yang perlu dipertimbangkan dalam implementasi pendidikan, sehingga pendidikan itu sesuai dengan latar belakang budaya yang melandasinya, dan dapat dilihat dari sudur pandang individu dan juga masyarakat. (Dahlan, 2006). Kebudayaan itu dibentuk oleh masyarakat, akan tetapi aqidah yang menjadi landasan agama akan mewarnai budaya serta segala kreasi yang lahir dari budaya itu. Gazalba (1978:12) seperti dikutip oleh M. Djawad Dahlan, menggambarkan bahwa Aqidah yang dimaknai iman merupakan azaz atau fondasi ajaran dalam amal Islam. Agama berdiri tegak diatas aqidah, sehingga agama tanpa aqidah bagaikan 
badan tanpa roh. Budaya merupakan kreasi manusia yang mengembangkan sistem nilai berdasarkan aqidah yang dianutnya (Dahlan,2006)Pendidikan mencakup seluruh proses yang membantu pembentukan pola pikir dan karakter manusia sepanjang hidup. Pendekatan Antropologi memberikan kontribusi dalam memberikan hasil studi tentang berbagai metode pendidikan di berbagai tempat. Pendekatan Antropologi adalah pendekatan Praksis Pendidikan, sehingga dari pendekatan ini muncul pertanyaan mungkinkan lahir teori pendidikan yang landasannya murni dari budaya tertentu ? Jika kita ingin perluas, pertanyaan ini maka pertanyaan yang ada adalah mungkinkah lahir teori pendidikan (grand maupun ground teori) pendidikan yang murni dari Islam? itulah pekerjaan rumah para ilmuwan Islam.

Pendekatan Sosiologi, secara garis besar ada tiga model (Adiwikarta,2007) yang dilakukan dalam pendekatan pendidikan (1) Model Struktur Fungsional, yang intinya ingin menjawab Apa fungsi pendidikan dalam kehidupan. (2) Model Konflik, meminimalkan dominasi penguasa terhadap pendidikan, Bowles dan Gintis menyatakan bahwa pendidikan dalam masyarakat kapitalis jelas-jelas bersifat kapitalis (Adiwikarta,2007). (3) Model analisis Kritis, yakni suatu model yang mencoba mendorong emansipasi, membela kepentingan kaum lemah yang terpinggirkan dan pembebasan masyarakat dari berbagai bentuk dominasi.

Pendekatan Psikologi, kontribusi dasar psikologi terhadap praksis pendidikan terutama berkaitan dengan perkembangan dan pembelajaran peserta didik dan metode serta penelitian pendidikan dari berbagai pendekatan atau aliran seperti psikologi Kognitif, Sosiokultural, Konstruktivisme, Perkembangan Moral dan Behavioristik. Dalam menjawab bagaimana membentuk sebuah manajemen yang sistemik pada jalur pendidikan formal, nonformal dan informal yang output dan outcomenya mampu memenuhi kebutuhan masyarakat dan bangsa dalam bersaing dengan tatanan kehidupan global dalam bidang ekonomi, Ilmu pengetahuan, dan teknologi, serta peradaban dunia.

Tantangan yang pertama terletak di tangan pembuat dan pelaku kebijakan pendidikan, kesadaran bahwa pendidikan di Indonesia yang berlandaskan keTaqwaan tidak membenarkan pendidikan kapitalis, perlu disadari lebih dulu. Landasan Filosofi Pancasila cukup untuk dijadikan sebuah pegangan kuat, bahwa Indonesia mengakui dan berlandaskan pada KeTuhanan Yang Maha Esa. Pemahaman ini berlandaskan pendekatan sosiologi, bahwa ada pengaruh yang kuat, antara filosofi sebuah negara, filosofi Penguasa, dengan implikasinya terhadap kebijakan yang dihasilkan. Untuk itu perlu dikaji lebih dalam cocokkah bentuk pembagian pendidikan Indonesia di bagi dalam tiga jalur ? Formal, NonFormal, dan Informal ? Apakah perlu dilakukan redefinisi terhadap istilah diatas? sebab kita tahu bahwa awal pembagian ini dilakukan di Amerika karena output pendidikan di Amerika tidak menyertakan outcome.

Kedua, Dalam hal Integrasi Manajemen penulis ingin memulainya dengan meniadakan Manajemen Pendidikan yang terpisah, antara Pendidikan Nasional dengan Pendidikan dibawah naungan Departemen Agama. Pengintegrasian perlu dilakukan di jajaran manajemen. Negara harus berani mengambil sikap untuk menentukan filosofi pendidikan Indonesia yang diambil dari Pancasila. Bahwa core Pendidikan Indonesia adalah Nilai-nilai Islam. Ini tidak berarti bahwa agama lain tidak boleh menyelenggarakan pendidikan, melainkan tanggungjawan terhadap masyarakat yang didominasi oleh masyarakat Islam haruslah menjadi tanggungjawab Negara.

Ketiga, Pendidikan adalah sebuah sistem baik terhadap objek maupun solusi yang akan dilakukan, pemahaman ini harus dijabarkan dalam sebuah Master Pendidikan Indonesia. Dimana pendidikan berkesinambungan dalam hal substansi, sementara dalam hal ilmu terapan pendidikan harus mengakomodasi tuntuzan zaman.

Keempat, menarik menggunakan pendekatan Antropologi dalam menyelesaikan masalah pendidikan, Apakah mungkin dimunculkan teori pendidikan dari sebuah budaya tertentu ( UPI, 2005 ) bagi penulis jawabnya sangat memungkinkan. Sebab selama ini grand teori pendidikan yang kita 
anut, karena masih menggunakan paradigma Barat mau tidak mau kita juga masih mengikuti mazhab Descartes dan Newtonian yang memisahkan jiwa dan tubuh. Harus ditemukan sebuah Grand dan/atau Ground Teori baru yang menghasilkan paradigma holistik (UPI, 2005) Artinya sangat di mungkinkan untuk menemukan Grand Theory yang jauh lebih tepat untuk digunakan oleh Ilmu-Ilmu Humaniora dan Pendekatan Manusia yang Holistik. Penulis berasumsi, bahwa Islam sebagai the way of life, dapat mengakomodir Pancasila sebagai way of life sebuah bangsa dengan pemaknaan kembali, sebab dalam pemikiran penulis Pancasila memiliki hidden filosofi yang pada masanya awalnya dulu tidak mungkin dilakukan secara terang-terangan. Dan ini disadari oleh the founding father Indonesia. Pada masa sekarang memang dibutuhkan seorang Muslim yang memiliki kapasista dan keberanian serta keyakinan yang kuat untuk memunculkan Ilmu dari khasanah Islam. Syed M. Naquib Al-Attas penulis anggap salah seorang yang sedang berusaha dalam membuat fondasi Teori Islam, dengan memulainya dari pendekatan pendidikan.

Indonesia, dengan sebagian besar muslim dan memiliki akar budaya pendidikan Islam yang telah lama ( Pesantren, Madrasah ) memungkinkan untuk memunculkan teori pendidikan yang paling sesuai dengan budaya Indonesia yang dihasilkan dari pendidikan asli Indonesia yaitu Pesantren. Yang dapat dikembangkan menjadi Madrasah, atau Pendidikan Islam setPesantren adalah Budaya Pendidikan asli Indonesia yang dilandasi Tawhid.

Penulis ingin mengulas sedikir pandangan penulis tentang apa yang terjadi saat ini, dan mencoba menggambarkan sebuah ilustrasi Proses Pendidikan Islam yang berkesinambungan sebagai berikut.

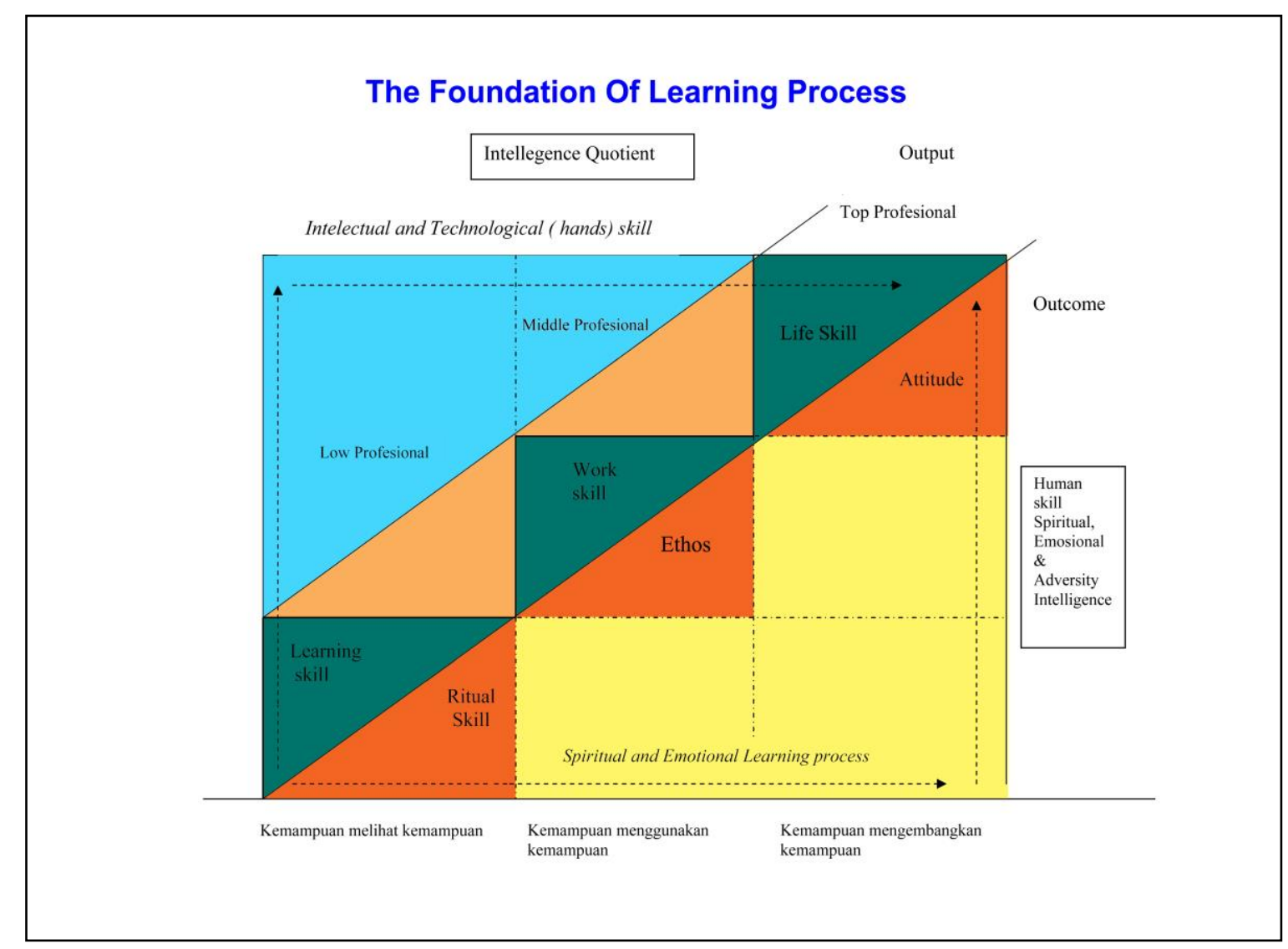

Dalam Bagan ini penulis mencoba mendiskripsikan, pendidikan yang ada saat ini dimana seharusnya apa yang dilakukan dapat menjadi lebih baik lagi. 
Pada tahap Learning Skill, seharusnya pendidikan membuahkan hasil penyadaran manusia akan eksistensi dirinya, lingkungan dan Tuhan, serta ketrampilan keberagamaan. Jenjang ini tidak terlalu statis berdasarkan jenjang pendidikan formal, tetapi lebih ditekankan pada bobot proses pendidikan yang dihasilkan. Pada pendidikan kapitalis manusia diberi bekal untuk memiliki kemampuan belajar dengan focus pada bidang Bahasa, Logika dan berhitung. Pada pendidikan pesantren, santri diberi bekal untuk dapat menjalankan ritual keagamaan dengan baik dengan focus Bahasa Arab, Al-Qur'an dan Hadits serta Fiqih. Jika saja kedua hal ini digabungkan, maka akan menghasilkan output dan outcome yang bagus. Kemudian pendidikan kapitalis diarahkan pada kecakapan bekerja (work skill) dengan bekal Bahasa International dan Informasi Teknologi. Pada pesantren dibekali dengan ketrampilan tangan, bertani, berdagang yang memunculkan ethos kerja yang iklas, lillahi ta'ala. Yang terakhir adalah Life skill, pada pendidikan kapitalis diarahkan pada Intelectual skill yang bergantung pada teknologi. Pada pendidikan pesantren diarahkan pada hands skill, yang membentuk dan menjadi sebuah sikap atau kepribadian yang tangguh (enterpreunership) Sesungguhnya, fondasi dari ketiga bentuk hasil proses pendidikan adalah : (1)Learning skill, penyadaran manusia akan kemampuan dirinya untuk belajar,(2)Work skill, adalah penyadaran manusia bagaimana menggunakan kemampuan yang dimilikinya (3)Life skill, adalah penyadaran manusia untuk mengembangkan terus kemampuannya dalam mempertahankan dan mengembangkan kehidupan yang berkualitas.

Ketika Pendidikan Kapitalis berlepas dari dari Spiritual and Emosional Learning process, maka ia akan kehilangan fondasi. Ketika pendidikan Islam (pesantren) meninggalkan Intelektual and Technologi Skill maka dia akan kesulitan dalam beradaptasi dengan zaman. Karena itu keduanya harus terintegrasi, dengan baik.

\section{HASIL DAN PEMBAHASAN}

Dari uraian di atas, menegaskan bahwa Indonesia harus segera memiliki Master Pendidikan Indonesia yang dimulai dengan Paradigma Islam sebagai the way of life, the way of thingking the foundations of learning process, yang mengejawantah dalam aspek filosofi kenegaraan. Kemudian lembaga-lembaga pendidikan Indonesia menggunakan kerangka yang sama dalam membuat Master Pendidikan Indonesia.

Dalam rangka itu lembaga-lembaga pendidikan Islam harus mendisain model-model pendidikan alternatif yang sesuai dengan kebutuhan perkembangan sekarang ini. Muncul pertanyaan modelmodel pendidikan Islam yang bagaimana? Yang diharapkan dapat menghadapi dan menjawan tantangan perubahan yang terjadi dalam kehidupan masyarakat baik sosial maupun kultural menuju masyarakat Indonesia baru. Untuk menjawab pertanyaan ini, meminjam prinsip hakekat pendidikan

Islam yang digunakan Hasim Amir, yang mengemukakan bahwa pendidikan Islam adalah pendidikan yang idealistik, yakni pendidikan yang integralistik, humanistik, pragmatik dan berakar pada budaya kuat (A. Malik Fadjar, Reorientasi Pendidikan Islam,:37). Penulis menyebutnya dengan pendidikan Holistik, sebab Islam tidak mengenal pemisahan, tetapi mengenal pembedaan.

Tawaran Hasim Amir ini, yang dikutip A. Malik Fadjar, dapat digunakan sebagai konsep pendidikan Islam dalam menghadapi perubahan masyarakat Indonesia, yaitu :

Pertama, pendidikan integralistik, merupakan model pendidikan yang diorientasikan pada komponen-komponen kehidupan yang meliputi: Pendidikan yang berorientasi pada Rabbaniyah [Ketuhanan], insaniyah [kemanusiaan] dan alamiyah [alam pada umumnya], sebagai suatu yang integralistik bagi perwujudan kehidupan yang baik dan untuk mewujudkan rahmatan lil 'alamin, serta pendidikan yang menggap manusia sebagai sebuah pribadi jasmani-rohani, intelektual, perasaan dan individual-sosial. Pendidikan integralistik diharapkan dapat menghasilkan manusia [peserta didik] yang memiliki integritas tinggi, yang dapat bersyukur dan menyatu dengan kehendak Tuhannya, menyatu dengan dirinya sendiri sehingga tidak memiliki kepribadian belah atau kepribadian mendua, menyatu dengan masyarakat sehingga dapat menghilangkan disintegrasi sosial, dan dapat menyatu 
dengan alam sehingga tidak membuat kerusakan, tetapi menjaga, memlihara dan memberdayakan serta mengoptimalkan potensi alam sesuai kebutuhan manusia. Dengan demikian, dapat dikatakan bahwa konsep pendidikan Islam adalah pendidikan yang bersumber dari konsep Ketuhanan [Teosentris], artinya pendidikan Islam harus berkembang dan dikembangkan berdasarkan teologi tersebut. Konsep kemanusiaan, artinya dengan konsep ini dapat dikembangnya antropologi dan sosiologi pendidikan Islam, dan konsep alam dapat dikembangkannya konsep pendidikan kosmologi dan ketiga konsep ini harus dikembangkan seimbang dan integratif.

Kedua, pendidikan yang humanistik, merupakan model pendidikan yang berorientasi dan memandang manusia sebagai manusia [humanisasi], yakni makhluk ciptaan Tuhan dengan fitrahnya. Maka manusia sebagai makhluk hidup, ia harus mampu melangsungkan, mempertahankan, dan mengembangkan hidupnya. Maka posisi pendidikan dapat membangun proses humanisasi, artinya menghargai hak-hak asasi manusia, seperti hak untuk berlaku dan diperlakukan dengan adil, hak untuk menyuarakan kebenaran, hak untuk berbuat kasih sayang, dan lain sebagainya. Pendidikan humanistik, diharapkan dapat mengembalikan peran dan fungsi manusia yaitu mengembalikan manusia kepada fitrahnya sebagai sebaik-baik makhluk [khairu ummah]. Maka, manusia "yang manusiawi" yang dihasilkan oleh pendidikan yang humanistik diharapkan dapat mengembangkan dan membentuk manusia berpikir, berasa dan berkemauan dan bertindak sesuai dengan nilai-nilai luhur kemanusiaan yang dapat mengganti sifat individualistik, egoistik, egosentrik dengan sifat kasih sayang kepada sesama manusia, sifat menghormati dan dihormati, sifat ingin memberi dan menerima, sifat saling menolong, sifat ingin mencari kesamaan, sifat menghargai hak-hak asasi manusia, sifat menghargai perbedaan dan sebagainya.

Ketiga, pendidikan pragmatik adalah pendidikan yang memandang manusia sebagai makhluk hidup yang selalu membutuhkan sesuatu untuk melangsungkan, mempertahankan dan mengembangkan hidupnya baik bersifat jasmani maupun rohani, seperti berpikir, merasa, aktualisasi diri, keadilan, dan kebutuhan spritual ilahiyah. Dengan demikian, model pendidikan dengan pendekatan pragmatik diharapkan dapat mencetak manusia pragmatik yang sadar akan kebutuhankebutuhan hidupnya, peka terhadap masalah-masalah sosial kemanausiaan dan dapat membedakan manusia dari kondisi dan siatuasi yang tidak manusiawi.

Keempat, pendidikan yang berakar pada budaya, yaitu pendidikan yang tidak meninggalkan akarakar sejarah, baik sejarah kemanusiaan pada umumnya maupun sejarah kebudayaan suatu bangsa, kelompok etnis, atau suatu masyarakat tertentu. Maka dengan model pendidikan yang berakar pada budaya, diharapkan dapat membentuk manusia yang mempunyai kepribadian, harga diri, percaya pada diri sendiri, dan membangun peradaban berdasarkan budaya sendiri yang akan menjadi warisan monumental dari nenek moyangnya dan bukan budaya bangsa lain (Fajar, 2005) Tetapi dalam hal ini bukan berarti kita menjadi orang yang anti kemodernan, perubahan, reformasi dan menolak begitu saja arus transformasi budaya dari luar tanpa melakukan seleksi dan alasan yang kuat.

\section{E. KESIMPULAN}

Selanjutnya, dari keempat model yang dikemukakan di atas, dapat ditarik lagi pada disain model pendidikan Islam yang lebih operasional, yaitu:

Pertama, mendisain model pendidikan umum Islami yang handal dan mampu bersaing dengan lembaga-lembaga pendidikan yang lain. Dengan demikian, visi, misi dan tujuan pendidikan, kurikulum dan materi pembelajaran, metode pembelajaran, manajmen pendidikan, organisasi dan sumber daya pendidikan [guru dan tenaga administrasi] harus disesukan dengan kebutuhan serta sesuai misi, visi dan tujuan pendidikan tersebut. Model pendidikan umum Islami, kurikulumnya bersifat integratif antara materi-materi pendidikan umum dan agama, sehingga mampu mempersiapkan intelektual Islam yang berfikir secara komprehensif. Atau meminjam istilah Fazlur Rahman, yaitu model pendidikan sekuler modern dan mengisinya dengan konsep-konsep Islam, untuk melahirkan 
intelektualisme muslim yang tangguh, walaupun Ahmad Syafii Maarif, menolak hal ini yaitu kita tidak perlu berteriak untuk mengislamkan ilmu modern.( Ada alasan lain bagi penulis, Ilmuwan Muslim perlu menggaungkan penemuan dalam Ilmu Modern yang telah diadapsi dengan Fondasi Islam, sebab ini akan bermanfaat bagi kalangan awam, yang memang harus diberitahu bahwa ada perbedaan yang signifikan antara Ilmu dalam Paradigma Barat dan Ilmu dalam Paradigma Islam).

Kedua, model pendidikan Islam yang tetap mengkhususkan pada disain "pendidikan keagamaan" seperti sekarang ini. Artinya, harus mendisain ulang model "pendidikan Islam" yang berkualitas dan bermutu, yaitu : [1] dengan merumuskan visi dan misi serta tujuan yang jelas, [2] kurikulum dan materi pembelajaran diorientasikan pada kebutuhan peserta didik dan kebutuhan masyarakat untuk dapat menjawab tantangan perubahan, [3] metode pembelajaran diorientasikan pada upaya pemecahan kasus [promlem solving] dan bukan dominasi ceramah, [4] manajemen pendidikan diorientasi pada manajemen berbasis sekolah, [5] organisasi dan sumber daya guru yang memiliki kompetensi dan profesional dalam bidangnya masing-masing. Maka pendidikan Islam akan mampu bersaing dengan mampu mempersiapkan dan melahirkan mujtahid-mujtahid yang tangguh, berkualitas dan berkaliber dunia dalam bidangnya sehingga mampu menjawab persoalan-persoalan aktual atau kontemporer sesuai dengan kebutuhan perubahan zaman. Disain model pendidikan seperti ini, harus secara "selektif menerima" pendidikan produk barat, berarti harus mendisain model pendidikan yang betul-betul sesuai dengan konsep dasar Islam dan sesuai dengan lingkungan sosialbudaya Indonesia. Kata Fazlur Rahman, apabila kita ingin membangun pendidikan Islam yang berkualitas, harus kembali kepada al-Qur'an dan Qur'an harus ditempatkan sebagai pusat intelektualisme Islam (Fazlur Rahman, 1985:1).

Ketiga, model pendidikan agama Islam tidak dilaksanakan di sekolah-sekolah formal tetapi dilaksanakan di luar sekolah. Artinya pendidikan agama dilaksanakan di rumah atau lingkungan keluarga, mesjid dan lingkungan masyarakat [tempat-tempat pengajian dan Masjid] dalam bentuk kursur-kursus, kajian-kajian keagamaan, keterampilan beribadah dan sebagainya. Pendidikan agama akan menjadi tanggungjawab orang tua dan masyarakat atau meminjam konsep Yahya Muhaimin yang dikemukakan terdahulu bahwa pendidikan berbasis keluarga [family-based education] dan pendidikan berbasis pada masyarakat [community-based education]. Pendidikan Islam, dapat ditanamkan dan disosialisasikan secara intensif melalui basis-basis tersebut, sehingga pendidikan agama sudah menjadi kebutuhan [need] dan based dalam pribadi peserta didik. Maka dalam proses belajar mengajar di sekolah pendidikan agama telah menjadi kebutuhan dan prilaku [afektif dan psikomotorik] yang aktual, bukan lagi berupa pengetahuan [knwoledge] yang dihafal [kognitif] dan diujikan secara kognitif pula.

Keempat, disain model pendidikan diarahkan pada dua dimensi, yakni: [1] dimensi dialektik [horisontal], pendidikan hendaknya dapat mengembangkan pemahaman tentang kehidupan manusia dalam hubungannya dengan alam atau lingkungan sosialnya. Manusia harus mampu mengatasi tantangan dan kendala dunia sekitarnya melalui pengembangan Iptek, dan [2] dimensi ketunduhan vertikal, pendidikan selain menjadi alat untuk memantapkan, memelihara sumber daya alami, juga menjembatani dalam memahamai fenomena dan misteri kehidupan yang abadi dengan Maha Pencipta (M. Irsyad Sudiro, 1995:2). Berati pendidikan harus disertai pendekatan hati, artinya pendidikan harus membangun hubungan manusia dengan Tuhannya, sesama manusia, dan lingkungan.

Keempat model pendidikan Islam yang dikemukakan di atas merupakan tawaran desain dan model pendidikan Islam yang perlu diupayakan untuk membangun paradigma pendidikan Islam dalam menghadapi perkembangan perubahan zaman modern dan memasuki masyarakat madani Indonesia. Kecenderungan perkembangan semacam, dalam upaya mengantisipasi perubahan zaman dan merupakan hal yang wajar-wajar saja. Sebab kondisi masyarakat sekarang ini lebih bersifat praktis-pragmatis dalam hal aspirasi dan harapan terhadap pendidikan, sehingga pendidikan tidak statis atau hanya berjalan di tempat dalam menatap persoalan-persoalan yang dihadapi pada era 
masyarakat modern, post masyarakat modern dan masyarakat global. Dengan demikian, apapun model pendidikan Islam yang ditawarkan dalam masyarakat Indonesia, pada dasarnya harus berfungsi untuk memberikan kaitan antara peserta didik dengan nilai-nilai ilahiyah, pengetahuan dan keterampilan, nilai-nilai demokrasi, masyarakat dan lingkungan sosiokulturalnya yang terus berubah dengan cepat, sebab pada saat yang sama pendidikan secara sadar juga digunakan sebagai instrumen untuk perubahan dalam sistem politik, ekonomi secara keseluruhan.

\section{DAFTAR PUSTAKA}

Abdul Azis, Syekh bin Nashir Al-Jalil. 2008. Tidakkah kalian berfikir?. Jakarta: Cakrawala. Ahmad Fuad, Al-Ahwani. 1997. Filsafat Islam. Cetakan VII. Jakarta: Pustaka Firdaus. Alatas, Fajrie, Ismail. 200., Risalah Konsep Ilmu Dalam islam. Jakarta: Diwan, Alatas, Fajrie, Ismail. 2007. Krisis Epistimologi dan Islamisasi Ilmu. Ponorogo Jatim: CIOS Al-Attas, Syed M Naquib. 1999. The Concept of Education in Islam. Kuala Lumpur: ISTAC. Almath, Faiz Muhammad. 1998. 1100 hadits terpilih. Jakarta: GIP

Al-Qur'an dan Terjemahnya. Madinah Munawwarah: Mujamma'Khadim al Haramain asy-Syarifain alMalik Fahd

Amiruddin. 2008. Pembaharuan Pendidikan Pesantren, Gama Media, 2008.

Amroeni, Drajat. 2006. Filsafat Islam, Jakarta: Erlanggan.

Arifin, H.M.. 1993. Filsafat Pendidikan Islam. Jakarta: Bumi Aksara

Arifin, H.M. 2006. Ilmu Pendidikan Islam, Tinjauan Teoritis dan Praktis berdasarkan Pendekatan Interdispliner. Jakarta: Bumi Aksara.

Arifin, M, 1991, Kapita Selekta Pendidikan. Jakarta: Bina Aksara.

Azis, Erawati, 2003. Prinsip-prinsip Pendidikan Islam. Jakarta: Tiga Serangkai

Azra, Azyumardi.,1999, Pendidikan Islam Tradisi dan Modernisasi Menuju Melenium Baru. Jakarta: Logo Macana Ilmu, .

Capra, Fritjof. 2007. The Turning Point, Titik Balik Peradaban, Sains, Masyarakat, dan Kebangkitan Kebudayaan. Bandung: Jejak

Capra, Fritjof. 2007. The Hidden Connection : Strategi Sistemik Melawan Kapitalisme Baru. Bandung: Jalasutra,.

Capra, Fritjof. 2007. The Tao of Physic, Menyingkap Kesejajaran Fisika Modern dan Mistisisme Timur. Jogyakarta: Jalasutra.

Dewantoro, Hajar., 1997, "Urgensi Inovasi Pendidikan dalam Pemberdayaan Umat", dalam : Muslih Usa dan Aden Wijdan SZ [Penyunting], Pendidikan Islam dalam Peradaban Industrialisasi, Aditiya Media, Yogyakarta.

Esposito , L John,. \& John O. Voll, 2001. Ismail Ragi Al-faruqi: Pioneer in Muslim - Christian Relation." In Maker of Contemporary Islam (Oxford: Oxford University Press)

Fadjar, A. Malik.. 1999. Reformasi Pendidikan Islam. Jakarta: Fajar Dunia.

Fadjar, A. Malik. 2000. Reorientasi Pendidikan Islam. Jakarta: Fajar Dunia

Goleman, Daniel. 1999. Kecerdasan Emosi untuk mencapai puncak prestasi. Jakarta: Gramedia

Goleman, Daniel. 2000. Kecerdasan Emosional, Mengapa EI lebih penting daripada IQ. Jakarta: PT Gramedia,

Goleman, Daniel. . 2004. Kepemimpinan berdasarkan Kecerdasan emosi. Jakarta: PT Gramedia

Hasan, Aliah B Purwakania. 2006. Psikologi Perkembangan Islam, Jakarta: PT. Radja Grasindo Perkasa. Hude, Darwis M. 2006. Emosi, penjelajahan Religio-Psikologis tentang Emosi Manusia di dalam AlQur'an. Jakarta: Erlangga,

Imarah, Muhammad. 2008. Manhaj Islami. Jakarta: Al-Ghuraba.

Zarkasy, Hamid Fahmi. 2005. Pendidikan Islam Terpadu. Artikel Majalah Islamia. Thn II No. 5 April Juni 2005, hal 9

Lang, Jeffrey. 2006. Aku Beriman, maka Aku Bertanya. Jakarta: Serambi,

Langgulung, Hasan. 1991. Kreatifitas dan Pendidikan Islam: Analisis psikologi dan falsafah. Jakarta:

Radar jaya Offset, 1991 
Langgulung, Hasan. 2000. Asas-asas Pendidikan Islam, Jakarta: Alhusna Zikra

Maarif, A.Syafii.. 1996. "Keutuhan dan Kebersamaan dalam Pengelolaan Pendidikan sebagai Wahana Pendidikan Muhammadiyah", makalah disampaikan pada Rakernas Pendidikan Muhammadiyah, di Pondok Gede. Jakarta: Muhammadiyah.

Mehdi Nakosteen. 1964. Kontribusi Islam atas Dunia Intelektual Barat, Deskripsi Analisis Abad Keemasan Islam, Risalah Gusti, II, 2003 Terjemahan dari History of Islamic Origins of Western Education A.D 800-1350 with an Introduction to Medieval. Colorado: Muslim Education

Moehadjir, Noeng. 1993. Ilmu Pendidikan dan Perubahan Sosial Suatu Teori Pendidikan. Edisi IV. Yogyajakarta: Rake Surasin

Muhaimin. 2006. Nuansa Baru Pendidikan Islam. Jakarta: Grafindo Persada

Muhaimin, Yahya [Menteri Pendidikan Nasional]. 2000. "Reformasi Pendidikan Nasional Munuju Indonesia". Majalah Dwiwutan BPK Penabur Jakarta, Midyawarta, No. 69/Thn.XII, From: http://www.bpkpenabur. or.id/ KPS. Jkt/ widya/69/69.

Perbagai Persoalan Pendidikan. 1991. Pendidikan Nasional dan Pendidikan Islam di Indonesia, Jurnal Pendidikan Islam, Kajian tentang Konsepo Pendidikan Islam, Problem dan Prospeknya, Volume 1 Tahun 1991, Fakultas Tarbiyah IAIN, Yogyakarta.

UNISIA. 1992, "Pendidikan Islam di Indonesia Merancang Masa Depan", UNISIA,No.12 Th. XIII,1992. Yogyakarta: UII.

Muhammad Imaduddin Abdulrahim, Islam Sisten Nilai Terpadu, GIP, Jakarta, 2002.

Mustapha Tajdin, Jalam Badi, Islamic Creative Thinking, Mizania, Bandung, 2008

Nasution, S, Berbagai pendekatan dalam proses belajar, Bumi Aksara, 2005

Nata, Abuddin, Paradigma Pendidikan Islam, Grasindo, 2001

Nawawi Al. Imam, Shahih Muslim, Terjemahan Hadits

Pasiaq, Taufik, Brain Management for Self Improvement, Mizan, 2007

Pasiaq, Taufik, Revolusi IQ/EQ/SQ antara neurosains dan Al-Qur'an, Mizan 2002

Purwanto, Agus, D.Sc. Ayat-Ayat Semesta, sisi-sisi Al-Qur'an yang terlupakan, Mizan, Bandung, 2008.

Rahman, Fazlur., 1985, Islam dan Modernitas tentang Transformasi Intelektual, Terj. Ahsin Mohammad, Bandung: Pustaka.

Riyadh, Saad, Jiwa dalam bimbingan Rasullulah, GIP, Jakarta, 2007

Rosidi Dedeng, Akar-akar Pendidikan dalam Al-Qur'an dan Al-Hadits, Kajian Semantik Istilah-istilah Tarbiyat, Ta'lim, Tadris, Tahdzib, dan Ta'dib. Pustaka Umat, Bandung, 2003.

Samsul Nizar Edt., Sejarah Pendidikan Islam, Menelusuri Jejak Pendidikan Era Rasullullah sampai Indonesia, Jakarta, 2007.

Sangkan Abu, Pelatihan Shalat Khusyu', Bukit Thursina, Jakarta, 2005

Shahih Muslim, Terjemah Hadits, Al Imam Nawawi, Klang Book Center, Selagor, Kuala lumpur, 1995.

Sherif Faruq, Al-Qur'an menurut Al Qur'an. Menelusuri Kalam Tuhan dari Tema ke Tema, Serambi, Jakarta, 1995.

Steenbrink, Karel A., 1994, Pesantren Madrasah Sekolah Pendidikan Islam dalam Kurun Moderen, Cet. Kedua, Jakarta: LP3ES,

Sudiro, M. Irsyad., Pendidikan Agama dalam Masyarakat Modern, Seminar dan Lokakarya Nasional Revitalisasi Pendidikan Luar Sekolah dalam Masyarakat Modern, Cirebon, Tanggal, 30 Agustus - 1 September 1995.

Sukardi, Imam, dkk. Pilar Islam - Bagi Pluralisme Modern, Tiga Serangkai, Solo, 2003.

Syafii Maarif, Ahmad., 1997, "Pendidikan Islam dan Proses Pemberdayaan Bangsa, dalam: Muslih Usa [Penyun.], Pendidikan Islam dalam Peradaban Industrialisasi, Aditya Media bekerja sama dengan Fakultas Tarbiyah UII, Yogyakarta.

Syamsul Ma'arif , Pesantren vs Kapitalisme Sekolah, Need's Press, 2008

Tabrani, Primadi, Kreativitas dan Humanitas, Jalasutra, Jogya, 2006.

Tabrani, Primadi, Proses kreasi, apresiasi, belajar, ITB Bandung, 2000

Tabrani, Primadi. Bahasa Rupa , Kelir, 2005

Tafsir, Ahmad, Epistemologi untuk Ilmu Pendidikan Islam, UIN Bandung, 1995

Tafsir, Ahmad, Filsafat Pendidikan Islami, Rosda, Bandung, 2006.

Tafsir, Ahmad, Ilmu Pendidikan dalam perspektif Islam, Rosda, 2005 edisi enam.

Taufiq, Muhammad Izzuddin, Psikologi Islam GIP, Jakarta, 2006 
Wan Daud, Wan Mohd Nor, The Educational Phylosophy and Practice of Syed Al-Attas, An Exposition Of the Original Concept of Islamization, ISTAC, Kuala Lumpur, 1998.

Yahya, Harun, Keajaiban Al-Qur'an, Sygma Arkanleema, Bandung, 2008 